\title{
Udvikling og brug af web-baserede apps
}

- til træning af kliniske færdigheder for medicinstuderende

\section{Yousif Subhi}

Forskningsassistent, stud.med.

Center for Klinisk Uddannelse, Center for HR, Region Hovedstaden

Klinisk $\varnothing$ jenforskningsenhed, Øjenafdelingen, Roskilde Sygehus.

\section{Kim Thestrup Foss}

Stud.med.

Center for Klinisk Uddannelse, Center for HR, Region Hovedstaden

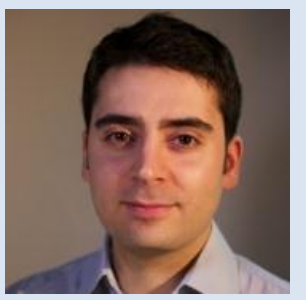

\section{Mikael J. V. Henriksen}

Klinisk assistent, læge

Center for Klinisk Uddannelse, Center for HR, Region Hovedstaden

\section{Tobias Todsen}

\section{Læge}

Center for Klinisk Uddannelse, Center for HR, Region Hovedstaden

Dronning Ingrids Hospital, Nuuk, Grønland
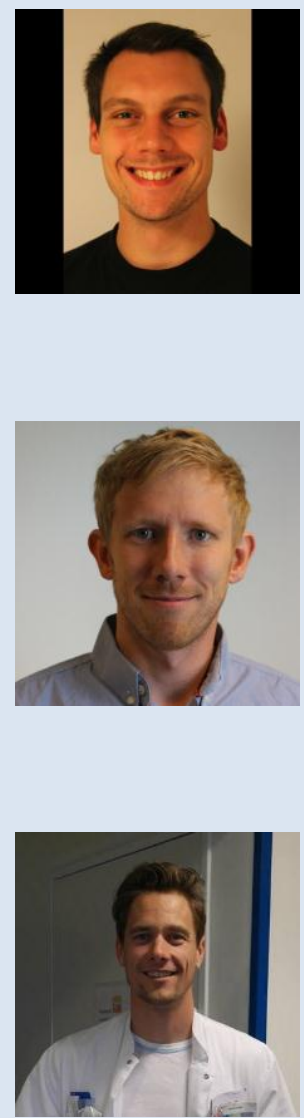


\section{Dansk abstrakt}

Uddannelsen til læge indebærer kliniske ophold, hvor medicinstuderende eksponeres for mange forskellige kliniske færdigheder. Opholdet foregår på mange specialafdelinger - men langt fra alle - og derfor kan det være svært at blive eksponeret for den bredde af kliniske færdigheder en læge skal beherske. Videoer er et udmærket læringsmedium til kliniske færdigheder, og med smartphones kan videoer distribueres, således at eksponering og formidling af kliniske færdigheder kan komme ud til de studerende i umiddelbar relation til deres behov. I denne artikel beskriver vi vores erfaringer med udvikling af en web-app med videoer af kliniske ledundersøgelser, og vores resultater om web-appens brug. Udvikling af web-apps og videoer er i dag ikke kun reserveret til de særligt teknisk kyndige, og kan udgøre en ny formidlingsplatform for kliniske færdigheder. Vi finder at web-appen har været brugt, og i artiklen diskuterer vi betydningen af brugsmønsteret og brugen af smartphones i klinikken.

\section{Engelsk abstrakt}

Medical students must undertake clinical rotations as a part of their education to learn practical clinical skills. Exposure to a sufficient range of practical clinical skills can be difficult to achieve given that a limited number of departments are visited. Videos are an excellent learning medium for clinical skills, and smartphones enable distribution of instructional videos to medical students just in time to an emerged clinical problem. In this paper, we describe our experiences with development of a web-app with videos of clinical joint examination and our results on the use of the web-app. Today, development of web-apps and videos are sufficiently simplified and enables clinical teachers to reach out to medical students on their smartphones. We find that our web-app was used, discuss the interpretation of this in this paper together with a discussion in general about use of smartphones in the clinic. 


\section{Baggrund}

Kliniske fardigheder på medicinstuderendes kliniske ophold

Uddannelsen til læge indebærer, udover tilegnelsen af akademisk viden, også et væsentlig element af tilegnelsen af kliniske færdigheder, såsom undersøgelsesteknik og udførsel af procedurer (Ringsted, 2004).

Medicinstuderende skal således lære motoriske færdigheder, som kræver en anden pædagogisk tilgang end den traditionelle akademiske universitetsundervisning. De kliniske færdigheder læres hovedsageligt på kliniske hospitalsophold af ugers varighed, hvor de studerende superviseret af læger skal lære forskellige færdigheder med en "see one, do one" tilgang (Ringsted, 2004).

Ifølge motorisk indlæringsteori er demonstration med efterfølgende eksperimentel udførsel essentielt for succesfuld tilegnelse af nye motoriske færdigheder (Magill, 2010). I en travl klinisk hverdag på specialiserede hospitalsafdelinger kan det være svært for de studerende at blive eksponeret for alle de nødvendige kliniske færdigheder, således at de både kan observere og efterfølgende udføre disse. (Mørcke \& Eika, 2002; Ringsted, 2004). Derfor er der i stigende grad implementeret simulationstræning af de kliniske færdigheder i medicinstuderendes curriculum. På Københavns Universitet forestås undervisningen i praksis af oplærte medstuderende, idet undervisningsudbyttet ved studenterundervisning kan være mere effektiv på baggrund af social og kognitiv kongruens (Tolsgaard et al., 2007; Ten Cate \& Durning, 2007). Imidlertid kan man ikke altid planlægge og sikre en efterfølgende praktisk træning ude på de kliniske afdelinger, (Mørcke \& Eika, 2002), og dermed kan der gå lang tid mellem træning og praktisk anvendelse.

\section{Kliniske instruktionsvideoer på smartphones}

Forskellige patienter har forskellige behov, og lægen er således nødt til at rumme meget viden og erfaring om forskellige færdigheder. Hukommelsen er imidlertid ikke er en uendelig ressource, og her foreslår Chueh og Barnett at en strategi kan være kun at lagre en del viden i hukommelsen, mens resten kan opsøges ved akut opstået behov, og ved gentagelse af et specifikt behov overgår viden med tiden til den faste hukommelse (Chueh \& Barnett, 1997). Kliniske instruktionsvideoer muliggør instruktion i en praktisk klinisk færdighed, kan foregå umiddelbart inden den konkrete kliniske procedure skal udføres, og kan derigennem være et godt supplement til den kliniske undervisning.

Videoer i online format giver adgang uafhængigt af tid og sted. Som undervisningsmodalitet finder flere studier at kliniske undervisningsvideoer kan være effektive (Xiao et al., 2007; Yeung, Justice \& Pasic, 2009), mens de omvendt også kan være uden læringseffekt hvis de ikke bruges af de medicinstuderende på en optimal måde (Todsen et al., 
2013). Interaktivitet og brugerbestemmelse er således vigtig for at de studerende kan bruge undervisningsmaterialet optimalt i forhold til eget vidensniveau (Mayer \& Moreno, 2003; van Merriënboer \& Sweller J, 2010). Dette kan opnås ved at lade de studerende tilgå videoerne via smartphones, som er vidt udbredte blandt medicinstuderende (Payne, Wharrad \& Watts, 2012; Robinson et al., 2013). Video-baserede smartphone apps kan derfor være en effektiv læringsplatform for kliniske færdigheder til medicinstuderende (Davis et al., 2012).

\section{Medicinstuderende bruger smartphones på kliniske ophold}

Medicinstuderende bruger i højere grad deres smartphones i uddannelsesmæssig sammenhæng når de er på kliniske ophold, og brugen drejer sig om opslag vedr. lægefaglig viden og færdigheder (Markman et al., 2013; Han, Nelson \& Wetter, 2014; Tran et al., 2014). Men patientkontakten spiller en nøglerolle for medicinstuderendes kliniske ophold, og i praksis er brugen af smartphones også påvirket af interaktionen mellem patienten og den studerende. Davies mfl. lavede et fokusgruppe interview af medicinstuderende udstyret med en personal digital assistant (PDA - en håndholdt computer) på deres kliniske ophold (Davies et al., 2012). Under interviewet fortalte en studerende at en PDA muliggjorde at man kunne se patienten og opsøge information samtidig, men at vedkommende aldrig kunne finde på at bruge den under en samtale; en anden studerende bemærkede nødvendigheden af at fortælle patienten hvad vedkommende gjorde med PDA'en for ikke at give patienten indtrykket af at være uopmærksom under patientsamtalen (Davies et al., 2012). Khalifian mfl. fulgte seks medicinstuderende på deres kliniske ophold og fandt at de studerende primært søgte på Google for at finde klinisk information, men at de studerende var tilbageholdende med at søge på Google foran patienten for ikke at give patienterne den opfattelse de skulle opsøge fremtidig hjælp på Google fremfor egen læge (Khalifian et al., 2013). Klinisk praksis kan byde på mange forskellige situationer - fra forholdsvis fredelige situationer med lidt ondt i halsen til mere intime situationer med sygdomme i kønsdele - og det er tænkeligt at patientens reaktion mod smartphone-brug kan være forskelige i forskellige situationer som kræver smartphone-relateret etikette - mobikette (Davies et al., 2012; Ellaway \& Masters, 2008) - og brugsmønsteret af smartphones på kliniske ophold kan således være særdeles kompleks og patientafhængig.

\section{Egenudvikling af smartphone apps}

Et studie af unge læger i USA viste at over halvdelen af disse brugte apps på deres smartphone som hjælp til at træffe kliniske beslutninger i hverdagen (Franko \& Tirell, 2013). Den kan således være problematisk for patient sikkerheden når kommercielle virksomheder prøver at sælge kliniske apps uden krav om faglig korrekt indhold gennem app-butikker som Apple App Store og Google Play (Lessin \& Ante, 2014). Kalz og kollegaer fandt således http://www.lom.dk 
at de færreste apps om genoplivning - en praktisk færdighed - overholdte gældende behandlingsguidelines, hvilket kan være afgørende for liv eller død i den akutte situation (Kalz et al., 2014). Hvis sundhedsrelaterede apps skal være bygget omkring faglig korrekt viden, er der derfor nødt til at være mere regulering af området (Charani et al., 2014), et peer-review system af apps (Eysenbach, 2014), eller at fagpersoner selv kan lave apps f.eks. med simple web-apps (Subhi et al., 2014). Web-apps muliggør også kryds-kompatibilitet, dvs. afvikling på tværs af systemer, hvilket er en stor fordel, da smartphone-markedet har flere store spillere som Apple iPhone, Google Android og Windows Phone, og udvikling af native apps til at dække alle disse platforme er omkostningstungt og tidskrævende (Ohayon, 2014). Godt video- og redigeringsudstyr koster i dag meget mindre end tidligere, og med implementering af disse i smartphones og tablets, er det blevet til allemandseje. Det muliggør at undervisningsvideoer kan laves på lokalt niveau for mindre midler (Malon et al., 2014). Samme tendens kan observeres indenfor smartphone app-udvikling hvor der i stigende grad udvikles redskaber der muliggør app-udvikling uden behov for programmering (Subhi et al., 2014; Snappii.com, USA; AppBaker.com, Cypern), hvorved app-idéer kan realiseres uden større omkostninger.

\section{Design af apps}

Apple anbefaler at apps overholder deres Human Interaction Guidelines (Apple Inc., 2014), en række af praktiske anbefalinger bygget op omkring grundidéerne omkring man-machine interaction (Booth, 1989), således at brugen af apps bliver mere intuitivt for brugerne. Man-machine interaction tager udgangspunkt i at software og hardware i sig selv ikke nødvendigvis er intuitiv, forståelig og tilgængelig for brugerne, og strukturen og designet af software og hardware kan være af afgørende betydning for brugerens interaktion (Booth, 1989). Rasmussen har helt tilbage til 70'erne beskrevet the man-machine interaction og understreget vigtigheden af at fokusere sit design specifikt til målgruppen inklusive den kontekst målgruppen anvender devicet i (Rasmussen, 1979). Udviklingsmiljøet for native iPhone apps er i lang udstrækning bygget omkring koncepterne fra Apples Human Interaction Guidelines for at facilitere interaktionen med brugeren, hvorimod ved udvikling af web-apps er udvikleren i højere grad efterladt til sig selv og selv må være opmærksom på brugervenligheden og strukturen af web-appen. Strukturen af en app kan have en væsentlig effekt på læringseffekten (Pimmer et al., 2013). Pimmer mfl. undersøgte effekten af multimedie-indhold i smartphone-medieret viden på medicinstuderende, og fandt at brugen af billeder gav væsentlig højere tilfredshed, mens kombinationen af lyd, billeder og billedforklaringer gav en væsentlig højere læringseffekt målt på viden (Pimmer et al., 2013). Mere overordnet kan man også overveje fremgangsmåden for beskrivelse af kliniske procedurer, som almindeligvis er en beskrivelse af definition, indikationer og kontraindikationer, materialer, udførsel og overvejelser 
efter proceduren - i ovenstående rækkefølge (Armbruster, Naqibullah \& Clementsen, 2014). Denne rækkefølge og fremgangsmåde behøver ikke at være lige god på tværs af forskellige medier, men der foreligger ingen klare studier herom. Indenfor simulationstræning anbefales det at man inden udviklingen af et simulationsprogram udfører en Training-Need-Analysis (Schout, 2010), og på samme måde må det anbefales at man inden udfærdigelsen af en app anvender en lignende strategi for afdækning af behovene hos målgruppen.

\section{Egenudviklet web-apps med kliniske instruktionsvideoer til medicinstuderende}

Formålet med denne artikel er at diskutere vores erfaringer med udviklingen af en video-baseret web-app i en klinisk færdighed for medicinstuderende. Vi vil også præsentere vores resultater om brugen af web-appen og gennemsyn af kliniske instruktionsvideoer.

\section{Fremgangsmåde}

\section{Ledundersøgelsen som et fokusområde}

Medicinstudiets kliniske kursus i medicin og kirurgi forløber på Københavns Universitet over 6. semester bachelor til og med 3. semester kandidat, og indebærer flere forskellige ophold på medicinske og kirurgiske afdelinger. Vi udvalgte disse semestre som målgruppe, og tog udgangspunkt i den praktiske færdighedsundervisning på deres 1 . semester kandidat forud for deres første længerevarende kliniske ophold. En del af de medicinstuderendes læringsmål omhandler at kunne undersøge kroppens led systematisk for mulig sygdom. Til dette modtager de på Københavns Universitet et 6-timers fokuseret 'hands on' kursus med en studenterunderviser i et færdighedslaboratorium. Herefter forventes det, at de studerende træner undersøgelsesteknikken på de patienter, hvor man kan mistænker ledsygdomme under deres klinikophold på hospitalerne. Ledundersøgelsen udvalgte vi som et fokusområde, idet denne færdighed i høj grad er motorisk, meget visuel, og samtidig kan være kompleks, hvorfor læring gennem apps med videoer i umiddelbar relation til akut opstået behov kan være velegnet.

\section{Forberedelse}

En projektgruppe bestående af to medicinstuderende, som underviser i ledundersøgelse og som har erfaring med udvikling af kliniske instruktionsvideoer, og to yngre læger på ortopædkirurgiske afdelinger, ligeledes med tidligere erfaring som studenterundervisere $\mathrm{i}$ ledundersøgelse, udviklede i fællesskab et oplæg til en app med videoer af ledundersøgelsen. Sammensætningen af gruppen sikrede at både undervisere med fornemmelse for de studerendes vidensbehov var repræsenteret, kombineret med yngre læger med erfaring for hvilken viden man som ung læge ofte efterspørger. 
Appen skulle indeholde både almindelige undersøgelsesteknikker, samt mere specifikke speciel undersøgelser for de enkelte led med udgangspunkt i hvad der er hyppigt forekommende i en skadestue samt pensum fra deres 6-timers kursus. Inden videooptagelserne blev der udviklet et filmmanuskript og et storyboard (en illustration af filmens visuelle komposition og forløb) for hvert afgrænset undersøgelsesområde (knæ, hofte, håndled, etc.). Udarbejdelsen af manuskriptet tjener primært til at sikre det faglige indhold, mens storyboardet sikrer en refleksion over hvordan man med kameraføring eller eventuelt illustrationer vil fremhæve sine faglige pointer. Udarbejdelsen af storyboardet kan være krævende og uvant, men vigtigheden må her understreges da det i betydeliggrad vil sikre en effektiv optageperiode samt et bedre resultat. Man kan i denne fase overveje prøveoptagelser for at se om f.eks. en given anatomisk struktur belyses tilstrækkeligt med den påtænkte vinkel mellem underviser og kamera. Manuskriptets indhold blev fagligt afstemt med niveauet af den planlagte undervisning på 1 . semester af kandidatuddannelsen. Herefter blev en professor i ortopædkirurgi rådført for vurdering af det klinisk faglige indhold.

\section{Optagelse af kliniske instruktionsvideoer}

Optagelserne foregik i et simulationslaboratorium, hvor der var opstillet tre-punktsbelysning, to Sony NXR-kameraer (Sony Corp., Japan) med tilhørende Sony Microports (Sony Corp., Japan) til video- og lydoptagelser. En studenterdrevet videoproduktionsenhed på Center for Klinisk Uddannelse (CEKU), CEKU Productions, stod for optagelserne, mens de to yngre læger fremviste undersøgelsesteknikken på simulerede patienter (Figur 1). De studerende havde ingen formel videouddannelse, blot interessen. Efterfølgende blev videoerne redigeret i Final Cut X (Apple Inc., USA) på en Apple Macbook Pro (Apple Inc., USA) og eksporteret $\mathrm{i}$ Quicktime Movie Format (.mov) til en online videolagrings-service (Vimeo.com, USA). Videoerne blev skjult fra resten af videolagringshjemmesiden for at undgå tilfældige visninger, og privacyindstillingerne blev sat således at videoerne kun var tilgængelige gennem direkte links.

\section{Udvikling af web-app}

Projektgruppen udarbejdede et flowchart for appens indhold, opbygning og brugerens valgmuligheder, og tegnede skitser for hvert enkelte frame. De diskuterede indholdet og gik i gang med app-udviklingen efter konsensus. Udviklingsstrategisk valgte vi web-apps, der er defineret som applikationer der afvikles i et web-browserunderstøttet programmeringssprog, som i praksis ofte er en kombination af Hyper Text Markup Language (HTML), Cascading Style Sheets og Javascript (Nations, 2014). Vi har udviklet en metode til web-app-udvikling som ikke kræver større tekniske færdigheder (Subhi et al., 2014), hvor man kan benytte drag-and-drop interfaces på eksisterende online jQuery-designværktøjer til http://www.lom.dk 
at generere HTML5-koder som samles i en fil til en web-app (Figur 2). Med denne metode udviklede projektgruppen en skabelon, som blev programmet yderligere mhp. finjustering og derefter uploadet til adressen http://led.cekuapp.dk. Web-appen kan føjes til hjemmeskærmen, hvilket betyder, at de på smartphones i praksis fungerer som native apps, så længe der er en fungerende internetforbindelse (Figur 3). Grundet vigtigheden af en for målgruppen synlig og populær distributionskilde (Masters \& Ellaway, 2008; Subhi \& Bitsch, 2014), blev distributionen af web-appen faciliteret gennem en annonce på Mediciner Organisationernes Kommunikationsorgan (http://www.mok.dk) som siden 1968 har udgivet et populært studenterblad der i praksis også fungerer som en kilde til officielle meddelelser fra universitetet til de studerende. Gennem vores web-hosting service (One.Com) indsamlede vi anonymiseret data omkring antal gange web-appen var indlæst, og gennem vores video-hosting service (Vimeo.com) indsamlede vi anonymiseret data omkring antal gange de $\mathrm{i}$ appindlejrede videoer var afspillet og hvor mange af dem var set til ende (gennemsyn).

\section{Erfaringer}

\section{Egenudvikling af instruktionsvideoer og web-app}

Vi producerede i alt 18 instruktionsvideoer, hvoraf 8 omhandlede standardundersøgelser og 10 specialundersøgelser (Tabel 1). Hver standardundersøgelse er en sammensætning af et antal basale undersøgelser og videoerne har en varighed på ca. 2-5 minutter. Et eksempel er skulderundersøgelsen som indebærer en inspektion af skulderens udseende, en palpation af skulderens knogler og led, og en undersøgelse af bevægeligheden af skulderen i forskellige planer.

Specialundersøgelser er fokuseret på en enkelt undersøgelse og varer ca. 20-50 sekunder. Hawkins test er et eksempel på en specialundersøgelse, hvor skulderen manipuleres på en specifik måde der vil udløse en smerte ved afklemning af skulderen. Videoerne blev indlejret i vores web-app, hvor vi til hvert undersøgelsesområde (led) tildelte en standardundersøgelsesvideo, et antal videoer om specialundersøgelser og et røntgenbillede af det raske led (Figur 4). Derudover beskriver vores app en basal introduktion til ledundersøgelse, hvor generelle overvejelser omkring enhver ledundersøgelse beskrives (Figur 4).

\section{Brugen af web-appen}

Web-appen blev udgivet ved semesterstart d. 27. januar 2014 (uge 5), og frem til d. 24. maj 2014 blev web-appen indlæst i alt 2989 gange (Figur 5). Annoncen blev trykt i MOK d. 12. Februar 2014 (uge 7), hvor web-appen i løbet af denne uge blev indlæst i alt 455 gange. Web-appen blev indlæst over hele ugen inklusiv i weekenden om end lidt mindre hyppigt (Figur 6). Indlæsningerne af web-appen fandt primært sted fra kl. 7 til 21 (Figur 7). 


\section{Gennemsyn af kliniske instruktionsvideoer}

Vores indlejrede videoer i web-appen blev afspillet i alt 909 gange, hvoraf 530 blev set fra start til slut (Tabel 2). Standardundersøgelserne havde i alt 644 afspilninger hvoraf $55 \%$ blev set helt igennem. Specialundersøgelserne blev afspillet 265 gange, og havde en højere gennemsnitlig fuldførselsrate på $66 \%$. Både for standardundersøgelserne og for specialundersøgelserne fandt vi at gennemførselsraten i nogen omfang var korreleret med varigheden af videoerne (Figur 8).

\section{Diskussion}

Vi har her beskrevet et eksempel på udviklingen af en video-baseret webapp i en praktisk klinisk færdighed, og dermed demonstreret, at det kan lade sig gøre for sundhedsprofessionelle og studerende at udvikle sådanne på egen hånd. Vores erfaring viser, at undervisere kan nå de studerende på smartphone-platformen på simpel og omkostningsfattig vis: Vores resultater viser at videoerne er afspillet 909 gange og set til ende i alt 530 gange (sv.t. minimum 20 timers undervisning).

Vi kan se en sammenhæng mellem annoncering i medicinstuderendes studentertidsskrift i uge 7 og et højt antal indlæsninger af web-appen, hvilket vi tolker som at appen blev præsenteret for målgruppen. De følgende uger svinger antallet af indlæsninger mellem ca. 100-300 per uge uden nogen klar sammenhæng med hvornår de studerende påbegynder et nyt klinikophold. De studerende møder på de kliniske ophold mandag til fredag, fra kl. 8 og til typisk kl. 15, mens vores web-app blev indlæst i alle ugens dage, hyppigst mellem $\mathrm{kl} .7$ og 21 . Vores metode retfærdiggør ikke at vi kan fastslå årsagen til dette. En mulig forklaring kan være at studerende i mindre omfang forventes også at deltage i aften- og nattevagter og enkelte tager også i klinik i weekenderne. I sådanne tilfælde er der færre personale til vejledning, hvorved de i højere omfang kan gøre brug af deres smartphones til at opsøge viden. Hardyman mfl. fandt at yngre læger bruger smartphones i klinikken til at læse om sygdomme og om kliniske procedurer, og at de yngre læger især finder smartphones brugbare når deres ældre kollegaer har travlt eller er mindre tilstede, f.eks. i nattevagter og i weekender (Hardyman et al., 2014). En anden forklaring på brugen af web-app om aftenen og i weekenderne kan være at de studerende ikke kun bruger deres smartphones til at opsøge viden i klinikken, men også supplerer læsning af lærebøger med videoer for at koble den teoretiske viden med praktiske undersøgelsesteknikker. Det kan også være svært at forestille sig hvordan f.eks. en skulderundersøgelse udføres, trods en adækvat tekstbeskrivelse i bogen, hvor det kan være oplagt at ligge bogen fra sig og i stedet hive telefonen op af lommen for at se videoer af undersøgelsen.

Vores videoer blev set fra start til slut i 42-94 \% af tilfældene, og de korte specialundersøgelser havde generelt en højere gennemførelsesrate end http://www.lom.dk 
standardundersøgelserne. Måske har de studerende oftere har styr på standardundersøgelserne pga. en større eksponering og derfor ikke føler at de behøver at se videoen til ende, mens specialundersøgelserne i højere grad kan være ny viden. En anden forklaring kan være at standardundersøgelserne er af længere varighed end specialundersøgelserne og at forskellen i gennemførselsraten skyldes forskelle i videoernes varighed. Vi finder en tendens til at videoers varighed hænger sammen med gennemførselsraten, således at kortere videoer har en højere gennemførselsrate, hvilket stemmer overens med erfaringerne fra den mobile reklamebranche, som viser en klar sammenhæng mellem videoers varighed og sandsynligheden for at kunden vil se videoen helt igennem (Mobile Marketing Association, 2014).

Vores fremgangsmåde har et antal begrænsninger som bør holdes in mente ved tolkning af vores fund. Selvom web-apps har en række fordele i krydskompatibilitet og mulighed for hurtig overgang fra udvikling til udgivelse sammenlignet med godkendelsesprocessen ved de etablerede app-markeder, så har web-apps også et antal væsentlige ulemper. Internetadgang er påkrævet, og ved dårlig mobilforbindelse kan adgangen til web-appen være begrænset, hvor en native app ville være upåvirket. Til vores web-app tog vi udgangspunkt i ledundersøgelsesundervisningen for de medicinstuderendes kursus i medicin og kirurgi, men adgangen til webappen var ikke begrænset til medicinstuderende, så vi kan ikke vide om vores tal om brugen er begrænset til medicinstuderende i de pågældende semestre. Medicinstuderende på 3. semester af bacheloruddannelsen har undervisning i bevægeapparatets anatomi, mens de på 4. semester af kandidatuddannelsen har kliniske ophold i neurologi, hvor de også undersøger bevægeapparatet, og det er meget tænkeligt at de også kan have gjort brug af web-appen. Læger kan også have brugt web-appen, især kan man forestille sig yngre læger i skadestuen som skal forholde sig til mange ledrelaterede problemer. Det kan heller ikke udelukkes at andre fagområder, f.eks. fysioterapistuderende, kan have benyttet sig af webappen. Vi har ikke indsamlet data om hvem der bruger web-appen, hvad web-appen bruges til eller hvor den bruges, og vores bud på forklaringer til brugsmønsteret om hvornår web-appen bruges og gennemsyn af videoerne bør derfor kun tolkes som vores overvejelser.

I denne artikel kan vi konkludere, at det med simple metoder er muligt at udvikle en video-baseret web-app som læringstilbud for de praktiske, kliniske færdigheder. Praktiske færdigheder læres også på andre uddannelser, som f.eks. sygeplejeuddannelsen, hvorfor vi mener at vores erfaringer med denne metode kan have interesse for en bred målgruppe. Vores data viser at vores web-app bliver brugt og antyder at dette læringstilbud måske ikke kun bruges i klinikken, men også i forbindelse med læsning. Studiet har dog metodologiske begrænsninger der gør, at vi kun kan komme med overvejelser om hvorfor vi ser de brugsmønstre vi http://www.lom.dk 
gør og ikke kan fastslå kausale årsager. Yderligere studier er påkrævet for at kortlægge de detaljerede aspekter af web-app-baseret læring. Særligt studier af brugeroplevelser af app og videoer, og deres modtagernes vidensbehov må efterlyses.

\section{Referencer}

Apple Inc. iOS Human Interface Guidelines. Hentet d. 28. Maj 2014 fra Apple Developer Library: https://developer.apple.com/library/ios/documentation/UserExperien ce/Conceptual/MobileHIG/MobileHIG.pdf

Armbruster, K., Naqibullah, M. \& Clementsen, P. F. (2014). Pleuracentese. Ugeskrift for læger, 176:V60468

Booth, P.A. (1989). An introduction to human-computer interaction. Lawrence Erlbaum Associates Ltd.

Charani, E., Castro-Sánchez, E., Moore, L. S. \& Holmes, A. (2014). Do smartphone applications in healthcare require a governance and legal framework? It depends on the application! BMC Medicine, 12:29.

Chueh, H. \& Barnett, G. O. (1997). "Just-in-time" Clinical Information. Academic Medicine, 72:512-517.

Davies, B. S., Rafique, J., Vincent, T. R., Fairclough, J., Packer, M. H., Vincent, R. \& Haq, I. (2012). Mobile Medical Education (MoMEd) - how mobile information resources contribute to learning for undergraduate clinical students - a mixed methods study. BMC Medical Education, 12:1.

Davis, J. S., Garcia, G. D., Wyckoff, M. M., Alsafran, S., Graygo, J. M., Withum, K. F. \& Schulman, C. I. (2012). Use of mobile learning module improves skills in chest tube insertion. Journal of Surgery Research, 177(1):21-26.

Ellaway, R., Masters, K. (2008). AMEE Guide 32: e-Learning in medical education Part 1: Learning, teaching and assessment. Medical Teacher, 30(5): 455-473.

Eysenbach, G. Contribute to mHealth research and development of the new JMIR mHealth peer-review tool for mobile apps! Hentet d. 26. Maj 2014 fra Journal of Medical Internet Research mHealth and uHealth: http://mhealth.jmir.org/announcement/view/78

Franko, O. I., Tirrell, T. F. (2012). Smartphone app use among medical providers in ACGME training programs. Journal of Medical Systems, 36(5): 3135-3139.

Han, H., Nelson, E. \& Wetter, N. (2014). Medical students' online learning technology needs. Clinical Teacher, 11(1):15-19.

Hardyman, W., Bullock, A., Brown, A., Carter-Ingram, S. \& Stacey, M. (2014). Mobile technology supporting trainee doctors' workplace learning and patient care: an evaluation. BMC Medical Education, 13:6. 
Lessin, J. E. \& Ante, S. E. Apps Rocket Toward \$25 Billion in Sales. Hentet d. 26. Maj 2014 fra The Wall Street Journal: http://online.wsj.com/news/articles/SB100014241278873232937045 78334401534217878

Kalz, M., Lenssen, N., Felzen, M., Rossaint, R., Tabuenca, B., Specht, M. \& Skorning, M.. (2014). Smartphone apps for cardiopulmonary resuscitation training and real incident support: a mixed-methods evaluation study. Journal of Medical Internet Research, 16(3):e89.

Khalifian, S., Markman, T., Sampognaro, P., Mitchell, S., Weeks, S. \& Dattilo J. (2013). Medical Student Appraisal: Searching on Smartphones. Applied Clinical Informatics, 4:53-60.

Magill, R. A. (2010). Motor Learning and Control: Concepts and Applications. McGraw-Hill.

Malon, M., Cortes, D., Andersen, J., Jensen, M. A., Mortensen, H. B., Nygaard, U., Poulsen, A., Sørensen, J. L. \& Greisen, G. (2014). Implementing video cases in clinical paediatric teaching increases medical students' selfassessed confidence. Danish Medical Journal, 61(4):A4805.

Markman, T. M. Sampognaro, P. J., Mitchell, S. L., Weeks, S. R., Khalifian, S. \& Dattilo, J. R. (2013). Medical student appraisal: applications for bedside patient education. Applied Clinical Informatics, 4(2):201-211.

Masters, K. \& Ellaway, R. (2008). e-Learning in medical education Guide 32 Part 2: Technology, management and design. Medical Teacher, 30(5):474-489.

Mayer, R. E. \& Moreno, R. (2003). Nine ways to reduce cognitive load in multimedia learning. Educational Psychology, 38:43-52.

van Merriënboer J. J. G. \& Sweller J. (2010). Cognitive load theory in health professional education: design principles and strategies. Medical Education, 44:85-93.

Mobile Marketing Association. Mobile Video Benchmarking Study. Hentet 27. Maj 2014 fra: http://www.mmaglobal.com/whitepaper/mobilevideo-benchmark-study

Mørcke, A. M. \& Eika, B. (2002). De forventede praktiske kliniske færdigheder og de nyuddannede læger. Ugeskrift for læger, 164(27):3531-3534.

Nations, D. Web Applications: What is a Web Application? Hentet 24. Maj 2014 fra About.com Web Trends: http://webtrends.about.com/od/webapplications/a/web_application.ht $\mathrm{m}$

Ohayon, O., Kaye, J., Rigby, M., Hanage, C. \& Cooper, J. The insiders' guide to mobile app promotion: top tips for marketing your app from industry experts: An in-depth step-by-step guide to making your app a success. 
Hentet 27. maj 2014 fra mobiThinking:

http://mobithinking.com/mobile-app-promotion-guide

Payne, K.B., Wharrad, H. \& Watts, K. (2012). Smartphone and medical related App use among medical students and junior doctors in the United Kingdom (UK): a regional survey. BMC Medical Informatics and Decision Making, 12:121.

Pimmer, C., Mateescu, M., Zahn, C. \& Genewein, U. (2012). Smartphones as Multimodal Communication Devices to Facilitate Clinical Knowlege Processes: Randomized Controlled Trial. Journal of Medical Internet Research, 15(11):e263.

Rasmussen, J. (1979). On the Structure of Knowledge - A Morphology of Metal Models in a Man-Machine System Context. Risø National Laboratory, RISØ-M-2192.

Ringsted, C.V., Pallisgaard, J. \& Falck, G. (2002). Lægers kliniske færdigheder efter turnusuddannelsen. Ugeskrift for læger, 164(24):3211-3215.

Ringsted, C. V. (2004). Klinisk lægeuddannelse i et fremtidsperspektiv. Ugeskrift for læger, 166(51):4715-4717.

Robinson, T., Cronin, T., Ibrahim, H., Jinks, M., Molitor, T., Newman, J. \& Shapiro, J. (2013). Smartphone use and acceptability among clinical medical students: a questionnaire-based study. Journal of Medical Systems, 37(3):9936.

Schout, B. M., Hendrikx, A. J., Scheele, F., Bemelmans, B. L. \& Scherpbier, A. J.. (2010). Validation and implementation of surgical simulators: a critical review of present, past, and future. Surgical Endoscopy, 24(3):536-546.

Storheim, K. \& Zwart, J-A. (2014). Musculoskeletal disorders and the Global Burden of Disease study. Annals of the Rheumatic Diseases, 73:949-950.

Subhi, Y. \& Bitsch, M. (2014). Anvendelse af video som forberedelse til stationsbaseret eksamen I medicin og kirurgi. Ugeskrift for læger, 176:V10120619.

Subhi, Y., Todsen, T., Ringsted, C., Konge, L. (2014). Designing web-apps for smartphones can be easy as making slideshow presentations. BMC Research Notes, 7:94.

Ten Cate, O. \& Durning, S. (2007). Dimensions and psychology of peer teaching in medical education. Medical Teacher, 29(6):546-552.

Todsen, T., Henriksen, M.V., Kromann, C.B., Konge, L., Eldrup, J., Ringsted, C. (2013). Short- and long-term transfer of urethral catheterization skills from simulation training to performance on patients. BMC Medical Education, 13:29. 
Tolsgaard, M.G., Gustafsson, A., Rasmussen, M. B., Høiby, P., Müller, C. G. \& Ringsted, C. (2007). Student teachers can be as good as associate professors in teaching clinical skills. Medical Teacher, 29(6):553-557.

Tran, K., Morra, D., Lo, V., Quan, S. D., Abrams, H. \& Wu, R. C. (2014). Medical Students and Personal Smartphones in the Clinical Environment: The Impact on Confidentiality of Personal Health Information and Professionalism. Journal of Medical Internet Research, 16(5):e132.

Yeung, P. Jr., Justice, T. \& Pasic R.P. (2009). Comparison of Text versus Video for Teaching Laparoscopic Knot Tying in the Novice Surgeon: A Randomized, Controlled Trial. Journal of Invasive Gynecology, 16:411415 .

Xiao, Y., Seagull, F. J., Bochicchio, G. V., Guzzo, J. L., Dutton, R. P., Sisley, A., Joshi, M., Standiford, H. C., Hebden, J. N., Mackenzie, C. F. \& Scalea, T. M. (2007). Video-based training increases sterile-technique compliance during central venous catheter insertion. Critical Care Medicine, 35(5):1302-1306. 


\section{Figurer}

Figur 1. Eksempel på videooptagelse hvor lægen underviser en simuleret patient.

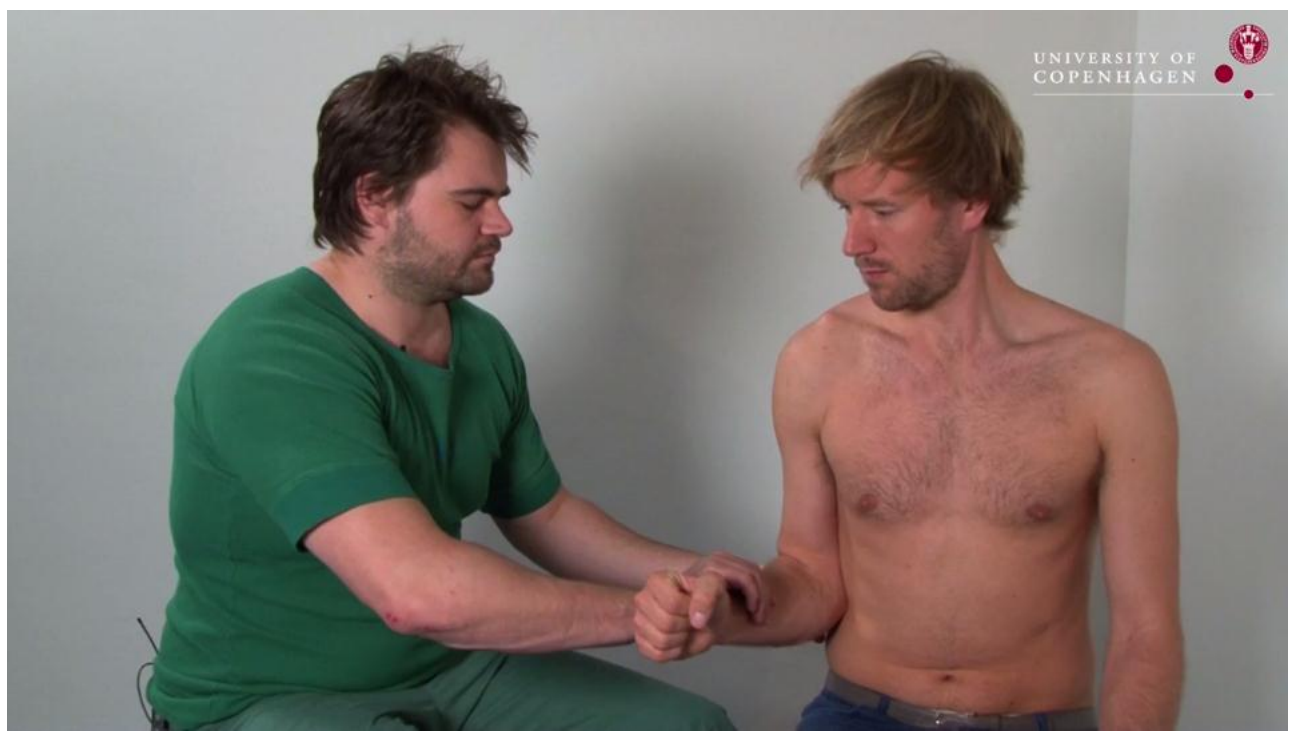

Figur 2. Simple online-tjenester muliggør drag-and-drop web-appudvikling.

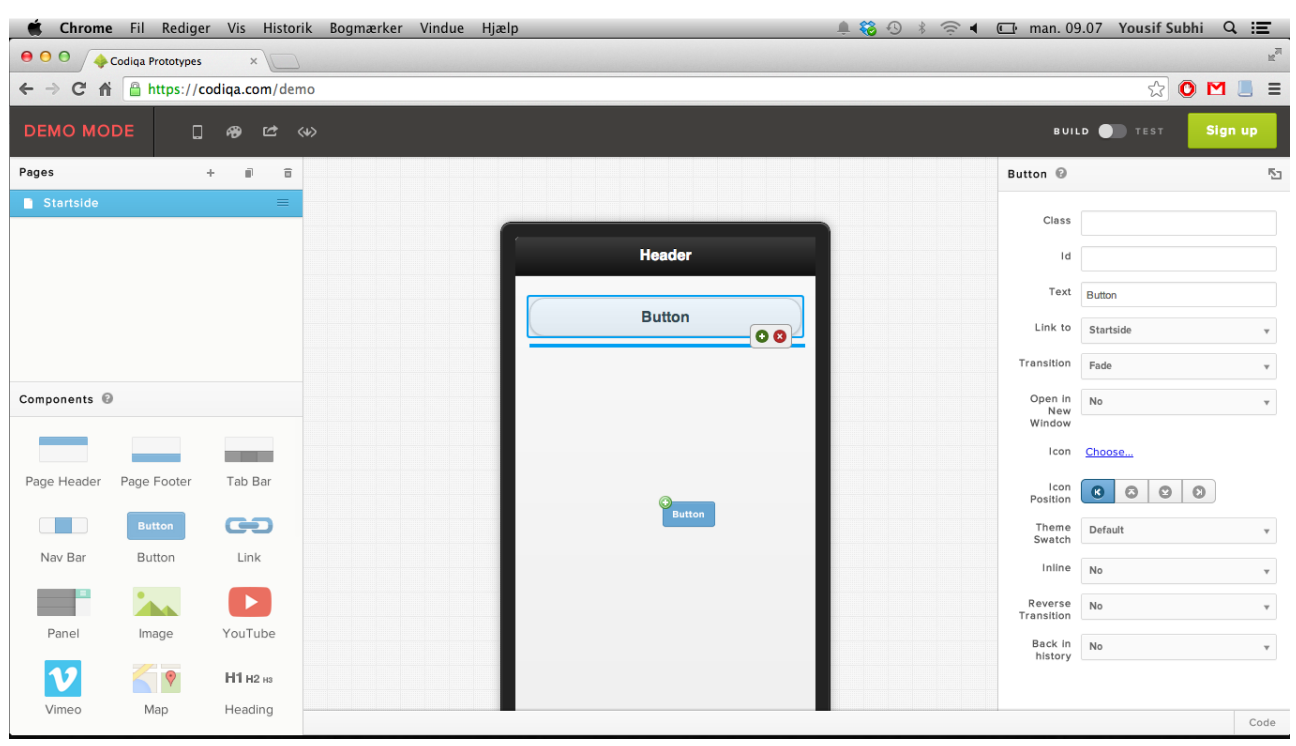


Figur 3. Web-apps kan gemmes som ikoner på hjemmeskærmen (top), hvorefter de i lang udstrækning kan fungere som native apps (bund).

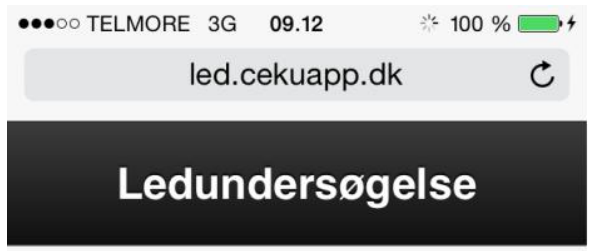

Intro: Generelle overvejelser for enhver ledundersøgelse.

Led: Videoklip med undersøgelsesteknik for de enkelte led.
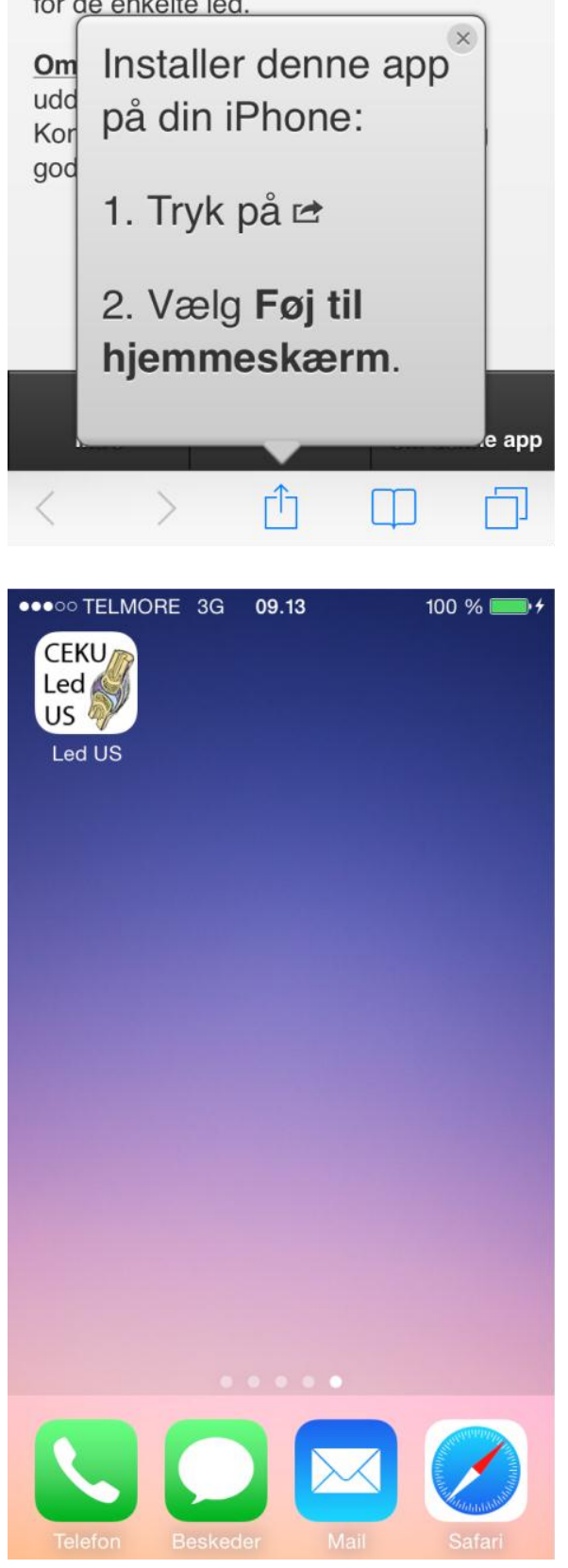

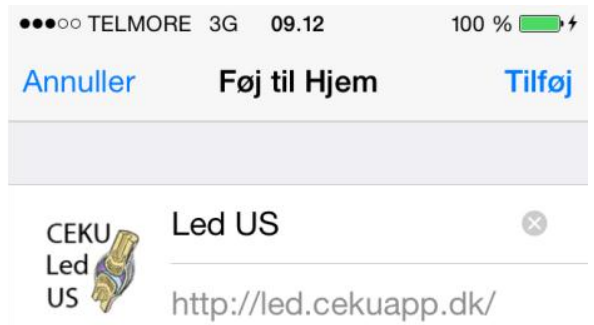

Der føjes et symbol til hjemmeskærmen, så du hurtigt kan få adgang til dette websted.
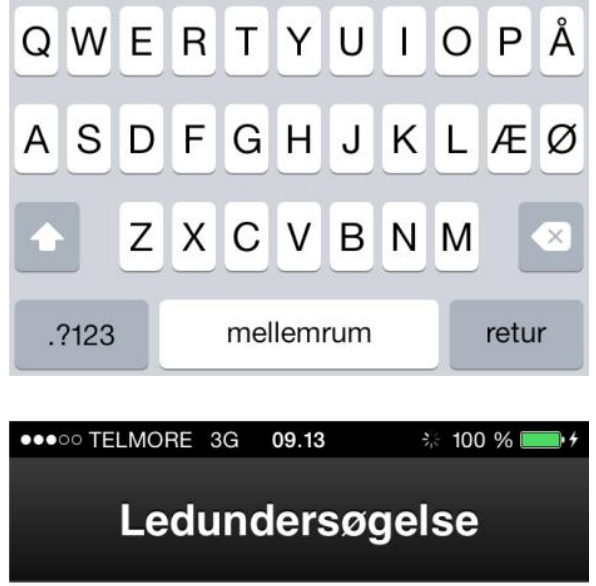

Intro: Generelle overvejelser for enhver ledundersøgelse.

Led: Videoklip med undersøgelsesteknik for de enkelte led.

Om denne app: Center for klinisk uddannelse har udviklet denne app. Kontakt os med dine kommentarer og gode idéer.

\begin{tabular}{|c|c|c|}
\hline 4 & $\mathbf{a}$ & $\mathbf{i}$ \\
Intro & Led & Om denne app \\
\hline
\end{tabular}


Figur 4. Web-appen er bygget op omkring en basal introduktion til ledundersøgelse, og undersøgelsesmetoder for kroppens forskellige led (top), hvor der for hvert område kan findes videoer (bund).

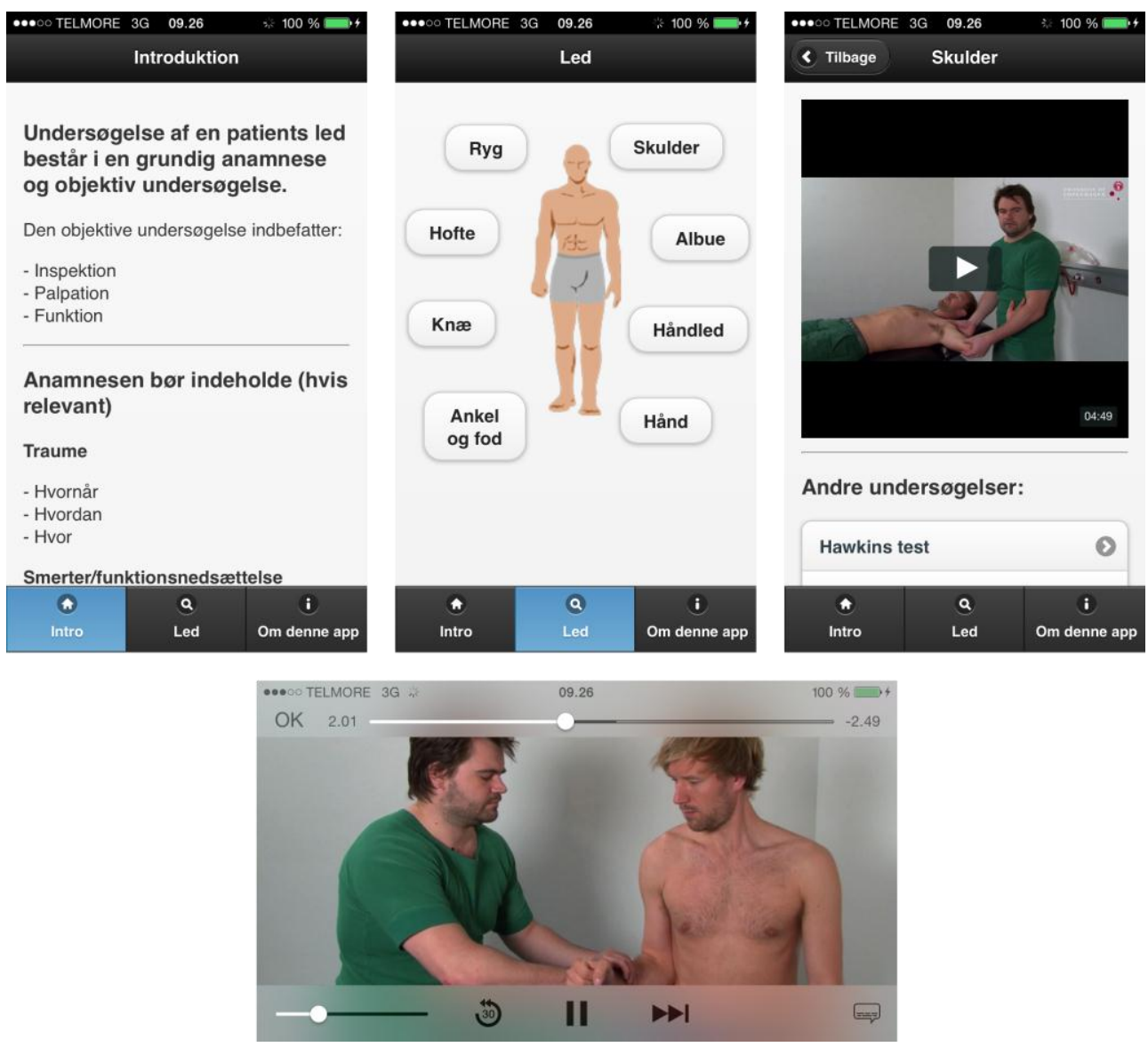


Figur 5. Antal indlæsninger af web-appen. Web-appen blev udgivet ved semesterstart i uge 5, og i uge 7 blev der indsat en annonce i et studentertidsskrift.

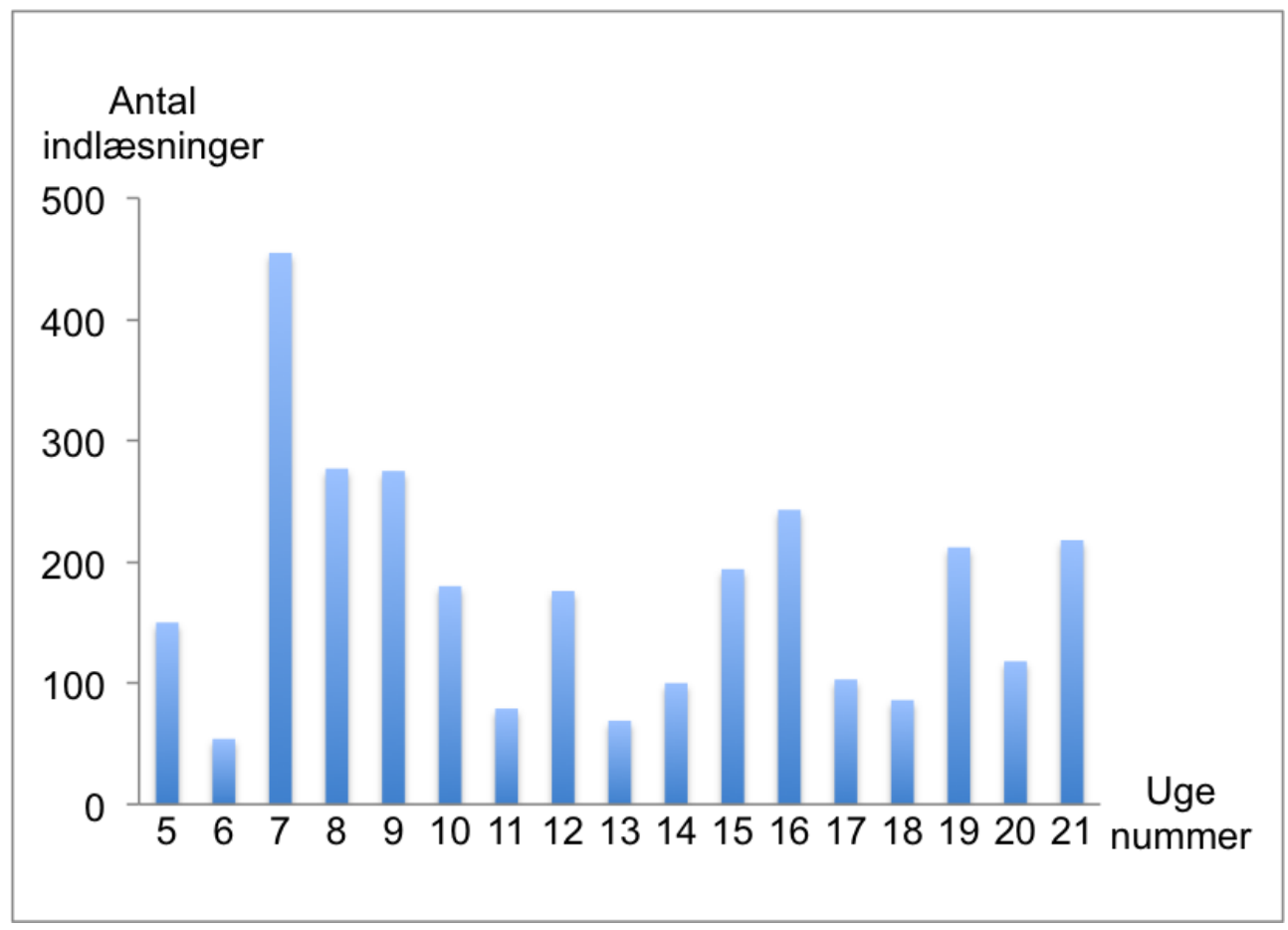


Figur 6. Web-appens brug over ugens dage som et gennemsnit af studieperioden.

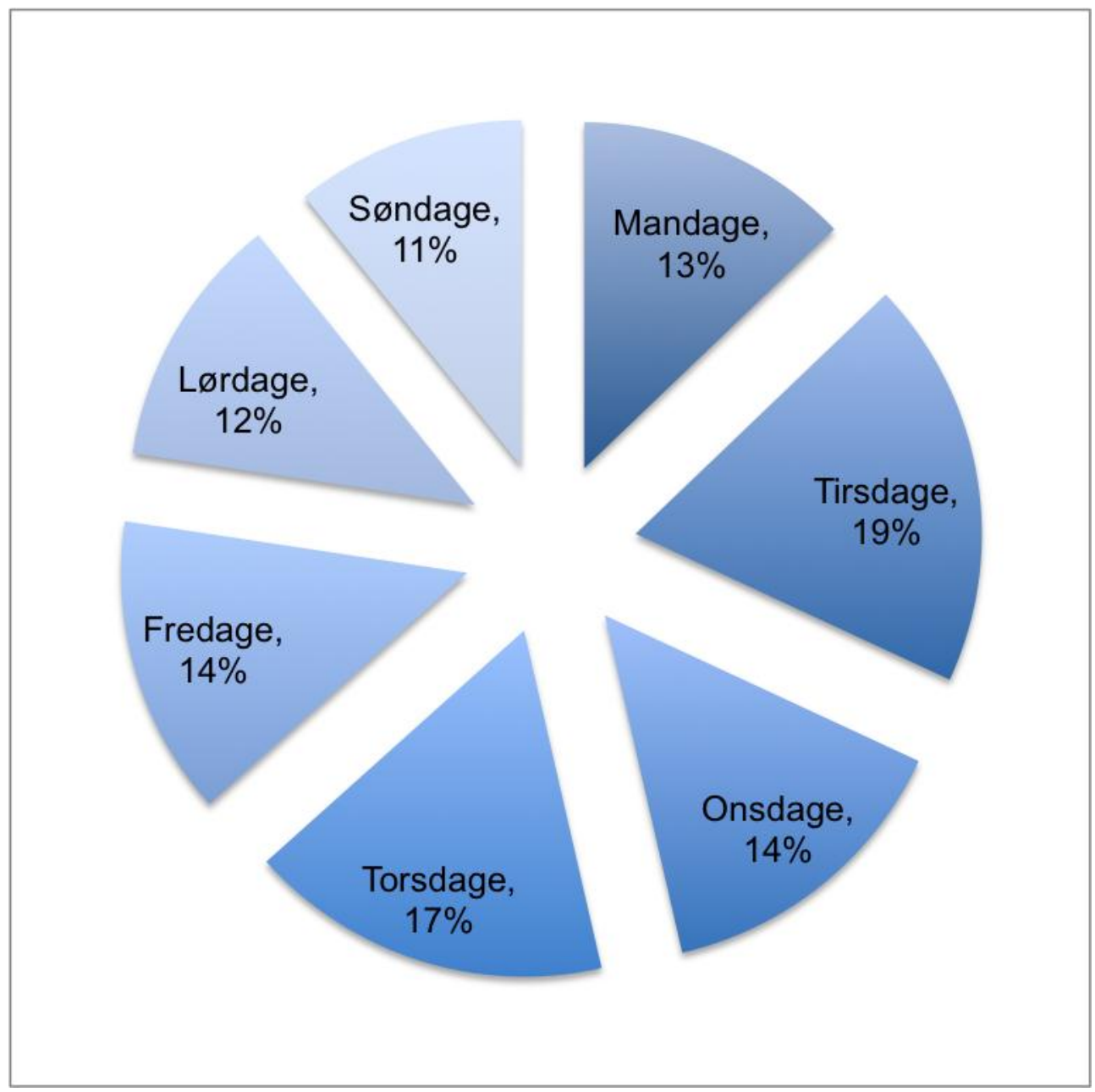


Figur 7. Web-appens brug i løbet af dagen som et gennemsnit af studieperioden.

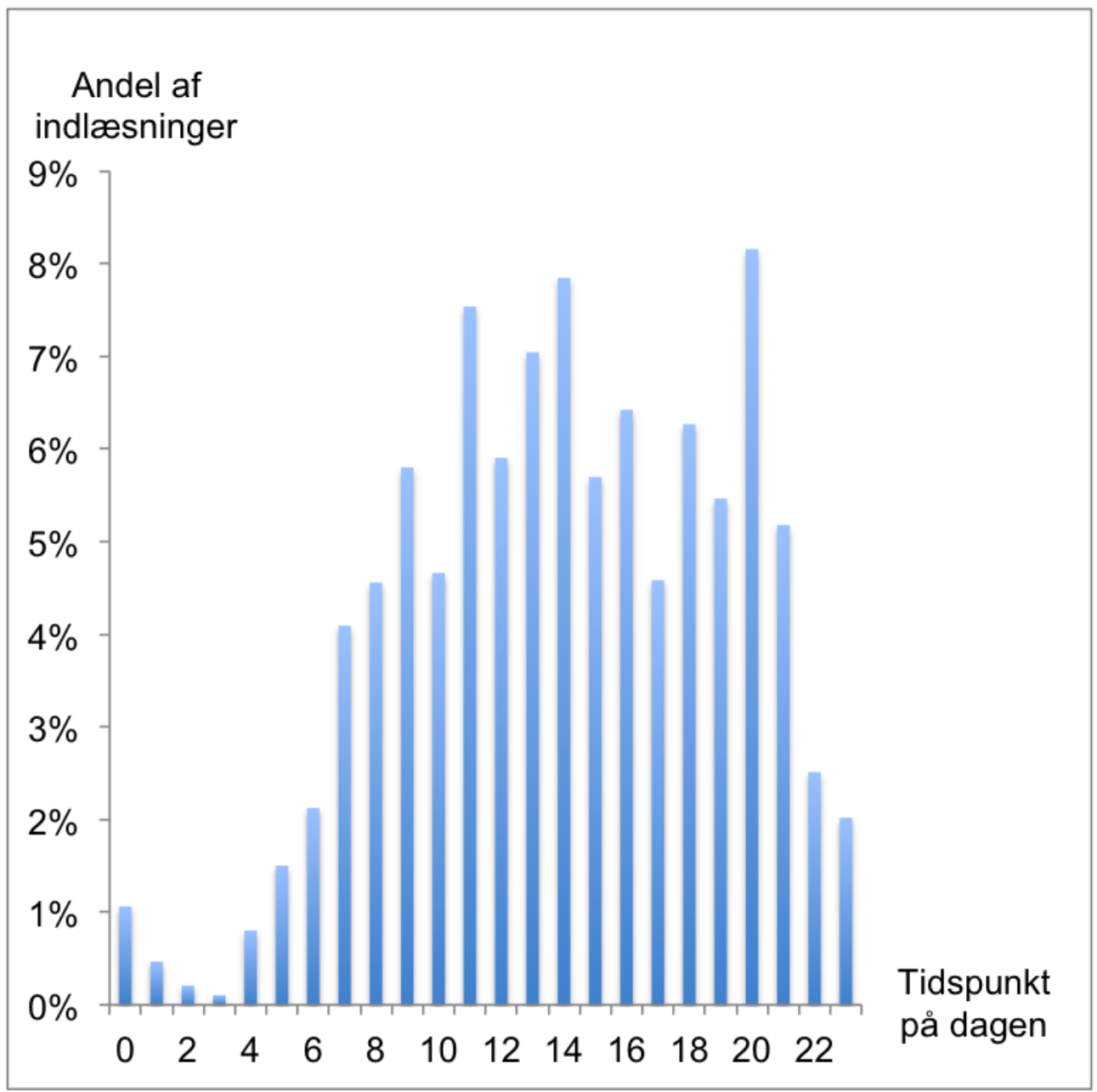


Figur 8. Spredningsdiagrammer med tendenslinje mellem længden af videoer og gennemsynsprocent for standardundersøgelser (top) og specialundersøgelser (bund).
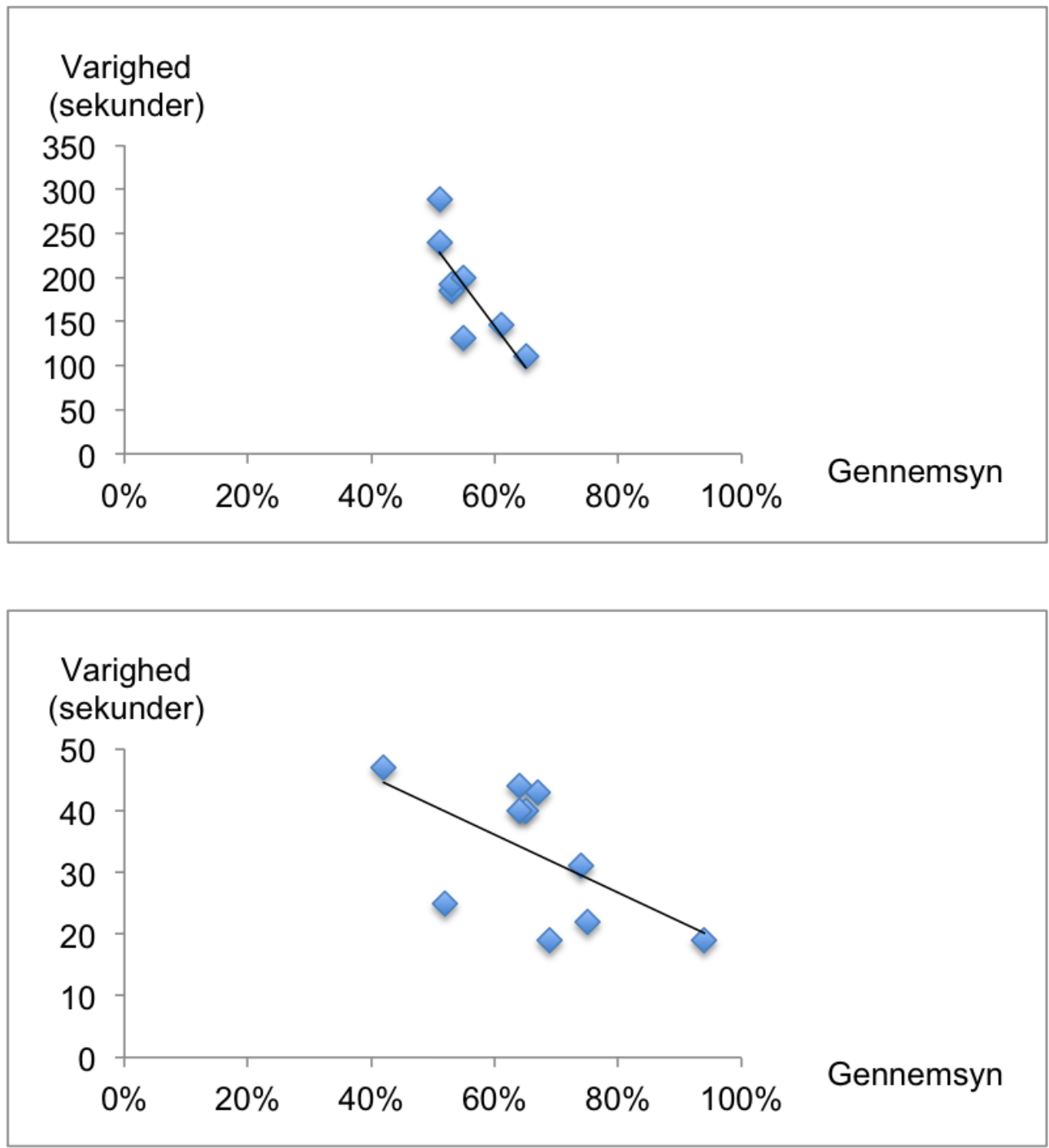
Tabel 1. Videoer i vores web-app.

\begin{tabular}{|c|c|c|}
\hline & $\begin{array}{l}\text { Varigh } \\
\text { ed } \\
(\mathrm{m}: \mathrm{s})\end{array}$ & URL \\
\hline \multicolumn{3}{|c|}{ Standardundersøgelser } \\
\hline Ryg & 03:59 & https://player.vimeo.com/video/74092142 \\
\hline Skulder & 04:49 & https://player.vimeo.com/video/74092753 \\
\hline Albue & $02: 12$ & https://player.vimeo.com/video/74092104 \\
\hline Håndled & $02: 26$ & https://player.vimeo.com/video/74092105 \\
\hline Hånd & 03:05 & https://player.vimeo.com/video/74092103 \\
\hline Hofte & 03:12 & https://player.vimeo.com/video/74092754 \\
\hline Knæ & 03:19 & https://player.vimeo.com/video/74092752 \\
\hline Ankel & 01:51 & https://player.vimeo.com/video/74092102 \\
\hline \multicolumn{3}{|l|}{ Specialundersøgelser } \\
\hline Ryg: Lasegue & 00:19 & https://player.vimeo.com/video/74609933 \\
\hline Ryg: Schobers & $00: 40$ & https://player.vimeo.com/video/74609934 \\
\hline $\begin{array}{l}\text { Skulder: } \\
\text { Apprehension- } \\
\text { Relocation }\end{array}$ & $00: 43$ & https://player.vimeo.com/video/74609909 \\
\hline Skulder: Hawkins & $00: 25$ & https://player.vimeo.com/video/74609911 \\
\hline Skulder: Sulcus & $00: 44$ & https://player.vimeo.com/video/74610937 \\
\hline Albue: Tennis & $00: 31$ & https://player.vimeo.com/video/74609907 \\
\hline Håndled: Tinnel & $00: 47$ & https://player.vimeo.com/video/74609910 \\
\hline Hofte: Piriformis & $00: 40$ & https://player.vimeo.com/video/74609931 \\
\hline Knæ: Kompression & $00: 22$ & https://player.vimeo.com/video/74609932 \\
\hline Ankel: Thomsons & $00: 19$ & https://player.vimeo.com/video/74609908 \\
\hline
\end{tabular}


Tabel 2. Antal afspilninger af indlejrede videoer og antal afspilninger hvor videoerne blev set helt igennem fra start til slut (fuldt gennemsyn).

\begin{tabular}{|c|c|c|c|}
\hline & $\begin{array}{l}\text { Antal } \\
\text { afspilning } \\
\text { er }\end{array}$ & $\begin{array}{l}\text { Antal fuld } \\
\text { gennemsy } \\
n\end{array}$ & $\begin{array}{l}\text { Andel } \\
\text { fuld } \\
\text { gennemsy } \\
n\end{array}$ \\
\hline \multicolumn{4}{|l|}{ Standardundersøgelser } \\
\hline Ryg & 87 & 44 & $51 \%$ \\
\hline Skulder & 99 & 50 & $51 \%$ \\
\hline Albue & 69 & 38 & $55 \%$ \\
\hline Håndled & 70 & 43 & $61 \%$ \\
\hline Hånd & 64 & 34 & $53 \%$ \\
\hline Hofte & 89 & 47 & $53 \%$ \\
\hline Knæ & 92 & 51 & $55 \%$ \\
\hline Ankel & 74 & 48 & $65 \%$ \\
\hline Standardundersøgelser i alt & 644 & 355 & $55 \%$ \\
\hline \multicolumn{4}{|l|}{ Specialundersøgelser } \\
\hline Ryg: Lasegue & 35 & 24 & $69 \%$ \\
\hline Ryg: Schobers & 40 & 26 & $65 \%$ \\
\hline Skulder: Apprehension-Relocation & 15 & 10 & $67 \%$ \\
\hline Skulder: Hawkins & 31 & 16 & $52 \%$ \\
\hline Skulder: Sulcus & 28 & 18 & $64 \%$ \\
\hline Albue: Tennis & 19 & 14 & $74 \%$ \\
\hline Håndled: Tinnel & 19 & 8 & $42 \%$ \\
\hline Hofte: Piriformis & 25 & 16 & $64 \%$ \\
\hline
\end{tabular}




\begin{tabular}{|l|c|c|c|}
\hline Knæ: Kompression & 36 & 27 & $75 \%$ \\
\hline Ankel: Thomsons & 17 & 16 & $94 \%$ \\
\hline \multicolumn{5}{|l|}{} \\
\hline Specialundersøgelser i alt & 265 & 175 & $66 \%$ \\
\hline Alle videoer & 909 & 530 & $58 \%$ \\
\hline
\end{tabular}

